\title{
Putting the Peter Parker Principle into Practice
}

Vertical Policy (Non-)Coordination on $\mathrm{CO} 2$ emissions reduction in Germany and Sweden

Maximilian Lennart Nagel and Jon Pierre

\section{(2) OpenEdition}

\section{Journals}

Electronic version

URL: http://journals.openedition.org/irpp/1123

DOI: $10.4000 /$ irpp. 1123

ISSN: 2706-6274

Publisher

International Public Policy Association

\section{Printed version}

Date of publication: 1 September 2020

Number of pages: 192-208

ISSN: 2679-3873

\section{Electronic reference}

Maximilian Lennart Nagel and Jon Pierre, "Putting the Peter Parker Principle into Practice",

International Review of Public Policy [Online], 2:2 | 2020, Online since 01 September 2020, connection on 29 January 2021. URL: http://journals.openedition.org/irpp/1123 ; DOI: https://doi.org/10.4000/irpp. 1123

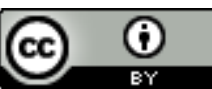




\section{Putting the Peter Parker Principle into Practice}

Vertical Policy (Non-)Coordination on $\mathrm{CO} 2$ emissions reduction in Germany and Sweden

\section{Maximilian Lennart Nagel}

Zeppelin University

\section{Jon Pierre}

University of Gothenburg

\section{Abstract}

Vertical coordination is a significant problem in many if not most countries. These problems are exacerbated in policy implementation related to issues that cut across jurisdictional borders. This paper compares policy implementation in the field of climate change, a quintessential example of such cross-cutting issues. In the context of $\mathrm{CO} 2$ emissions reduction policies, the Peter Parker principle states that vertical coordination presupposes not just central government control but also its responsibility. Our contribution to that argument is that the divorce between regulatory authority and formal jurisdiction challenges the principle. The present paper studies how these issues play out in two different types of institutional contexts; those of Germany and Sweden.

\section{Keywords}

vertical policy coordination, multi-level governance, climate policy 


\section{Introduction}

This paper explores the complexities of vertical coordination of the reduction of greenhouse gas emissions, the main cause of climate change, in Germany and Sweden. These complexities stem from a combination of autonomous agents, information and resource asymmetries, and an extraordinarily "wicked" policy problem. Much of our attention on policy coordination so far has been directed at horizontal policy coordination (see, for instance, Peters, 2015, 2018). We will argue that vertical policy coordination-aligning central government programs with those of autonomous regions and local authorities-poses an equally complex challenge as coordinating agencies, NGOs and societal actors, if not only more so. The significance of institutional values is particularly important in central-local relations where norms of subnational autonomy and self-government raise constitutional barriers to coordination. In addition, member states of the European Union (EU) must also factor in the EU's programs and directives into their domestic policy making, adding further institutional complexity and vertical coordination challenges.

We have found that although formal, institutional constraints prevent the federal/central government from relying on a strict top-down method of coordination, actors on all institutional levels strategically explore ways to reduce asymmetries between formal authority and resources. Moreover, the EU and the federal/central government achieve some degree of coordination by relying less on coercive instruments and more on incentives, thus circumventing constitutional obstacles to control cities and regions. Thus, with only minor exaggeration would we say that in both countries there is fair degree of vertical policy coordination, not because of the formal institutional arrangements but despite them.

Public policy making and implementation reflect a complex blend of ideas, objectives and values embedded in institutional arrangements, political and administrative agency, and professional norms shaping government action. Policies and programs addressing different issues related to climate change are no exceptions to this pattern. The policy problem is often described as the quintessential "wicked problem" (Head and Alford, 2015; FitzGibbon and Mensah, 2012); indeed, the potential impact of full-scale climate change would have a major impact on society and the economy. At the same time, public policy to mitigate climate change is frequently resisted by social groups such as private industry and farmers and their political representatives.

One particularly vexing issue is derived from the complex institutional arrangement within which climate change programs are embedded. In many countries, central government controls regulatory instruments and financial resources while subnational government, by virtue of constitutional norms of local autonomy, own many of the specific policy issues that are part of the climate change policy cluster (Linander, 2019; Meadowcroft, 2007). Thus, institutional and financial leverage is essentially divorced from issue ownership; while member-state governments have the financial means and expertise required to design and fund policy towards reducing greenhouse emissions, they lack formal authority over autonomous cities, where the bulk of greenhouse emissions occur and where targeted measures should be implemented. Cities, on the other hand, have such authority but often lack the necessary resources and knowhow to design and implement appropriate programs to reduce greenhouse emissions. Coupled with the increasingly active role of the EU in the environmental policy field, this disjuncture has propelled the emergence of complex multilevel governance arrangements seeking to align jurisdiction with institutional and financial capabilities across different institutional levels. 
This complex institutional context and its apparent inability to comprehensively address salient policy challenges has brought back central-local relationships onto the political agenda in many countries. In Sweden, for instance, the partially failed or insufficient response to the recent COVID-19 pandemic has to a large extent been attributed to problems associated with the vertical coordination of decentralized healthcare and elderly care systems (Pierre, 2020). It is thus no coincidence that Sweden, over the past decade, has witnessed a marked increase in both the range and the specification of central government's steering and control efforts over subnational government (Statskontoret, 2019a, b). Some of this increasing control may well have political motives although a good part may also simply be a matter of boosting vertical policy coordination.

Germany offers an even more complex case, one where local government enjoys extensive autonomy vis-à-vis higher echelons of government, but where the Länder interact both with the federal government and with cities. The specific nature of these institutional relationships varies considerably across different policy sectors.

The Peter Parker Principle, named after the action movie hero Spider Man, states that "with great powers come great responsibilities." This principle is fundamental to constitutional design where authority is linked to accountability. In the present context, the principle states that vertical coordination presupposes not just central government control but also its responsibility. Our contribution to that argument is that the divorce between regulatory authority and formal jurisdiction challenges this fundamental principle. Thus, unlike horizontal policy coordination, vertical policy coordination in political systems with constitutionally guaranteed local and regional autonomy frequently tends to challenge or even violate that principle.

Our study draws on Most Different Systems Design (MDSD), where cases ideally differ on all relevant aspects except for the key dependent variable, which in our study is vertical policy coordination (Peters, 1998; Przeworski and Teune, 1970; see also Przeworski, 1987). In this design, we have conducted a comparative case study project observing vertical policy coordination in two different institutional frameworks: a federal state and a unitary state. The MDSD approach is the preferred research design, allowing as it does for vast differences in independent variables and where similarities are found at the sub-system level (Przeworski and Teune, 1970). Embedded in these two differently organized states, there are important similarities, such as the autonomy of cities, which have a significant impact on policy implementation and local initiatives. This distinction facilitates an analysis of different multilevel governance arrangements in the greenhouse emissions policy sector in two different political systems.

The methodology used in the paper is a qualitative method based on, and synthesizing, previous research. There are several studies on how cities and regions seek to tackle greenhouse emissions and to develop green technologies for transport, district heating and heat storage and similar projects.

The next section of the paper reviews the institutional organization and coordination of climate change policy. We then turn to a brief outline of the basic tenets of multilevel governance theory before we introduce and compare processes of vertical policy coordination in the two countries. A concluding discussion wraps up the paper.

\section{Institutional politics and issue ownership in climate change policy}

A major governance challenge associated with climate change is that while global challenges call for global solutions, the source of much of what causes climate change is found in the grow- 
ing cities of the world. Thus, cities are part of both the problem and the solution: "Cities are the locations where most of the (un)sustainability issues find their origin. At the same time, cities are the basic units for policies that have significant environmentally beneficial consequences (both local and global) [...]" (Nevens et al., 2013:111). Some (see for instance Hammer et al., 2011:34) emphasize the economic opportunities that the development of green technologies has to offer cities: "The greening of the traditional urban economy and expanding the green urban sector can generate growth (through increased supply and demand), job creation and increased urban attractiveness. These effects are in part the result of stronger interactions at the urban level among economic efficiency, equity and environmental objectives."

Cities play a major role in causing climate change, particularly greenhouse gas emissions. Today, cities account for 70 percent of all greenhouse gas emissions. It is estimated that in 2050 , 75 percent of the world's population will be living in urban areas (Juncker, 2015). However, cities are embedded in institutional hierarchies, framed by structures such as the nation state and (in Europe) the EU. As we will discuss in detail later, cities vary widely with regard to their activity and strategic choices in climate change policy: some form local networks with industry and stakeholders; some collaborate with other cities domestically and internationally; while some take a more passive stance. While the EU multilevel governance arrangement to address climate change is challenging to navigate for cities, it is also ripe with opportunities for collaboration both across the public-private divide and across national and jurisdictional borders (Pierre, 2019).

\section{The policy problem}

We mentioned in the introduction that climate change is often understood as a typical "wicked problem": slippery to define; characterized by "strong complexity, uncertainty and ambiguity" (Hustedt, 2014:153), and more or less impossible to address efficiently (Head and Alford, 2015).

Climate change policies can be divided into two main policy fields; mitigation and adaptation. Climate change mitigation policies address in general causes of climate change. Greenhouse gas emission reduction is an example of a mitigation policy. Adaptation policies, by contrast, deal with preparations for addressing the consequences of global warming, for instance protecting coastal cities from flooding. Some adaptation actions have characteristics of a private good as benefits of actions may accrue more directly to the individuals, regions, or countries that undertake them, at least in the short term. Nevertheless, financing such adaptive activities remains an issue, particularly for developing countries (IPCC, 2014).

The EU has taken a high profile in this policy sector. Thus, for 2020, the EU committed itself to reduce greenhouse gas emissions by 20 percent compared to 1990; in 2030 emissions are supposed to be down to 60 percent; and by 2050 the EU aims to cut emissions by 80-95 percent. Furthermore, EU member states need to promote and sponsor renewable energy projects and reduce their energy consumption.

The strategy addressed several issues that were identified as main boundaries in the promotion of climate policies. The main issues concerned financial as well as personal resources (McCallum et al., 2013). The EU has created financial incentives and funding opportunities for member states and their cities in order to promote climate change policies. However, most EU policies towards environmental protection and climate change are directives, offering member states discretion for interpretation in their national policy making. Hence, the outcome of a directive differs from one member state to the next. 
Thus, importantly, EU member states maintain their own environmental policies. The implementation of EU policies depends largely on the good will of the member states and their capacity to coordinate between different levels such as the European, federal and municipal levels.

Embedded in this complex governance system, cities and municipalities find themselves torn between serving as agents implementing national obligations on the one hand, and setting their own priorities, strategies and objectives on the other (Bulkeley and Kern, 2006). In order to compensate for their limited formal and legal leverage in this policy field, cities find other sources of leverage and capacity act by increasing cooperation within and across national borders. Over the past 10-15 years, international networks of cities (frequently sponsored by the EU) have evolved to help cities build capacity to address the challenge of greenhouse gas emissions (Betsill and Bulkeley, 2006). These networks disseminate knowledge and expertise on climate change-related issues, outline strategies and formulate policy goals for their members (Gore, 2010; Pierre, 2019; Sharp et al., 2011).

\section{Vertical policy coordination in a multilevel governance setting}

We will now step back from our empirical analysis for a moment and discuss the broader implications of aligning issues related to vertical policy coordination with multilevel governance, which is the predominant mode of governance of environmental policy in the EU.

\section{Multilevel governance of climate change}

What we have described so far is a textbook case of multilevel governance in the EU. Our task now is to outline a framework which integrates multilevel governance and vertical policy coordination.

The multilevel governance framework allows us to observe how political agency evolves through interaction among institutional levels (Bache and Flinders, 2004; Bulkeley and Betsill, 2005; Hooghe and Marks, 2003; Piattoni, 2010). Multilevel governance in the EU draws to a large extent on negotiated relationships between different institutional levels and incentives rather than command and control patterns of vertical policy coordination. Equally important, the EU version of multilevel governance is essentially non-hierarchical; we see numerous examples-not least in climate change policy and environmental policy-of the EU Commission approaching cities and regions rather than communicating through the capital of the member states. This behavior is to a significant extent explained by the limited formal authority that the EU has in these policy areas. As a result of those constraints, the EU will support networks and offer incentives to subnational governments to address those issues.

Multi-level governance draws on the notion that "decision making competencies are increasingly shared between actors operating at different levels of governance" (Betsill and Bulkeley, 2006:149). Piattoni (2010) points out that multilevel governance fosters an exercise of a slightly different form of political authority, which represents a shift from attention to the center towards focusing on the periphery; a shift from the national to the international arena; and a shift from the public towards the private, bringing in stakeholders and relying on incentives and market mechanisms. Together, these shifts imply an exercise of a contextualized and negotiated form of political authority where policies and programs to a large extent are opportunity structures for subnational agents rather than directives for execution (Peters and Pierre, 2001, 2004; Pierre, 2019).

This means that as we study vertical policy coordination, we need to not just observe how this works domestically but also in relationship to the EU. It also means that while formal 
chains of command certainly matter, so do softer instruments like incentives or invitations to knowledge-based networks. These informal and contextually defined instruments thus operate alongside formal institutional relationships. And finally, integrating multilevel governance and vertical policy coordination, we should be open to a much less hierarchical order of policy making and implementation and that ideas and policy concepts can flow not only top-down but also bottom-up.

\section{Vertical policy coordination}

One of the most salient problems in contemporary government is that of coordinating policies and programs in order to boost efficiency, impact and outcomes (O'Flynn et al., 2013; Peters, 2015). While coordination has always been a challenge to governments, the problem has been exacerbated along with growing societal complexity, diffused knowledge and expertise, and the increasing saliency of policy problems - national security and safety, pandemics, climate change, migration, etc. - that traverse policy sectors and institutional borders.

At the same time, however, governments around the world are still predominantly structured according to different policy sectors. There is good reason for this arrangement; while the functional organizational paradigm has proven to be conducive to sectorization, these often denigrated "silos" or "stovepipes" do provide for specialization and the accumulation of expertise better than any other organizational model (Verhoest and Bouckaert, 2005). Thus, the heart of the problem is that the more public institutions become knowledgeable and expert-oriented, the bigger the problems in convincing them to team up with institutions in other policy sectors and to develop a joint agenda and plan of action.

The obstacles to working across boundaries are not confined only to the nature of the policy problems or growing social complexity. Problems with bending or integrating organizational cultures and with defining hierarchies among institutions at the same nominal level of organization like government departments or executive agencies loom large in processes aimed at increasing horizontal coordination. In addition, pooling resources across sectoral borders and ensuring accountability are perennial problems in horizontal coordination. As O'Flynn et al. (2013) show, the nature of these different problems varies, as do the strategies employed in different national contexts to ameliorate them. Arguably, different institutional and constitutional settings to some extent explain this cross-national variation in coordination strategies.

The literature on policy coordination is, perhaps for obvious reasons, mainly preoccupied with horizontal coordination among central government institutions in different policy sectors (Peters, 2015, 2018). However, there also is a vertical dimension of policy coordination whereby central, regional and local government seek to align policies and programs and policy design links up with policy implementation (Adam et al., 2019). Also, and most prominently in the European context, transnational institutions use economic or regulatory resources to try to shape domestic programs, thus adding an additional institutional level to the coordination process.

Perhaps the most important challenge to vertical coordination is the extent of autonomy accorded subnational government; the more extensive subnational autonomy, the more complex the vertical policy coordination (Adam et al., 2019). If we look specifically at the climate change policy sector, vertical policy coordination is essential since, as pointed out earlier, much of greenhouse gas emissions occur in cities while formal legal and regulatory authority and financial resources rest with national institutions. Thus, there needs to be some consistency among the three levels in terms of policy targets and measurements (Linander, 2019). 
In the current analysis, we need to consider not just how coordination is achieved; of equal importance is the question of what needs to be coordinated. For instance, is policy coordination mainly a matter of harmonizing policy objectives; or does coordination refer to synchronizing policy instruments; or is coordination a mechanism to ensure that programs are implemented in a similar fashion across the territory? Furthermore, vertical policy coordination is often fraught with issues related to how the funding required to implement central government programs is to be divided between central and subnational government where central government frequently relies on "unfunded mandates" to relocate financial responsibilities to the local level (Pierre, 2013). Thus, if anything, vertical policy coordination is at least as challenging as horizontal coordination, if not more so.

Vertical and horizontal policy coordination are closely intertwined processes which cannot be fully understood without considering both dimensions of coordination. This is particularly the case in jurisdictions with extensive regional or local autonomy. Given that much of the policy coordination literature explicitly or implicitly draws on the UK or US experiences-countries with very limited local autonomy (Gurr and King, 1987) — the vertical coordination dimension has received far less attention. We argue, however, that ensuring that actors and institutions at all tiers of government have a shared understanding of policy objectives and instruments is just as essential to policy success as horizontal policy coordination the central government level.

\section{Vertical policy coordination in a multilevel governance context}

The consolidation and continuing integration of the EU presents member-state institutions with a new type of challenge. Multilevel governance refers to more than merely adding another institutional level to the system of governance (see, for instance, Bache and Flinders, 2004; Hooghe and Marks, 2003; Peters and Pierre, 2001; Piattoni, 2010); the interaction between institutions at different levels is more negotiated and sometimes even defined ad hoc than in more conventional intergovernmental relationships. The case of $\mathrm{CO} 2$ emissions reduction policy illustrates this issue.

This contextualization of policy making and implementation has several important consequences. One such consequence is related to the flow of ideas and the location of expertise in the system. Cities may experience that nation-state policies have unintended consequences when implemented at the local level and seek to communicate those issues to central government and help shape future policies. Several studies show the significant role of local government in shaping policy choice and design at the national level (Gustafsson, 1987; Rhodes, 1986).

Add to this complex picture the EU and the global level and the extent to which policy coordination in a multi-level governance setting poses a significant challenge becomes even clearer. Thus, the vertical coordination of climate change-related policies and programs does not necessarily follow a strict top-down and ordered process; it is as likely to be top-down as bottomup, or could evolve through an interactive and iterative process among different institutional levels (Torfing et al., 2012). These fluid, ad hoc coordination processes are fertile soil for networks connecting agency at different institutional levels where cities and regions cooperate to share knowledge and extract resources from higher institutional echelons (Betsill and Bulkeley, 2006; Pierre, 2019).

We also note that there is a significant undercurrent to the decentralized pattern of environmental policy in the form of court appeals on local governments' building permits for power 
plants which are likely to have an environmental impact (Majone, 1997). For example, administrative rulings to impose stricter rules on industrial processes potentially damaging the environment are sometimes appealed and end up in the court system for a considerable period of time.

\section{Vertical climate change policy coordination in Germany and Sweden}

We will now turn to our case studies of vertical policy coordination in Germany and Sweden.

\section{Germany}

Germany is not among the forerunners in environmental protection, at least when it comes to the establishment of agencies and policy programs. In 1971, the first Environmental Protection Program was agreed on and led towards the installment of Germany's Environment Protection Agency (Umweltbundesamt), in 1974, following the example of Sweden and the United States.

Since 1972, policymaking in the environmental field is mainly carried out by the federal government. Until 2006, the Bundesländer were tasked with the protection of landscapes and nature. As EU policies gained increasing importance, coordination between the different levels became more difficult. Since 2006, Länder and municipalities have been in charge of the implementation, whereas legislation remains with federal institutions. In addition, most German Bundesländer have their own environmental protection policies.

German environmental policies were completely reassessed after the nuclear accident at Fukushima. The so-called Energy Transition (Energiewende) was passed by the CDU/FDP coalition in 2011, signifying the shift towards renewable and sustainable energies. Key parts of the program are the phase-out of nuclear reactors by 2022 and emissions reductions, which include the retirement of the coal-fired power plant generation. The overall goal is to have a sustainable energy system in place by 2050. The Energiewende is geared to foster three main policy goals; supply security, economic efficiency, and environmental protection.

Vertical and horizontal climate change policy coordination in Germany is rather complex. Peters (2018) points out that both types of coordination are particularly important in federal systems. Due to the federal structure and the constitutional autonomy of local authorities, five levels matter; the global sphere, the EU, the central government, the 16 constituent states, and the more than 11,000 municipalities.

Most climate-change related legislation takes place at the federal level. However, most state governments also pursue their own agenda and have their own climate change policies. As a result, conflicts occasionally arise when Länder set different priorities than the federal government. Such conflicts might, for example, lead to an expansion of renewable energy sources at non-optimal locations (Wurster and Köhler, 2016).

The Energy Saving Ordinance (EnEV - Energieeinsparverordnung) established in 2007 is a case in point which illustrates the difficulties of vertical coordination and the problematic relationship between the federal state, the Länder and municipalities. While the requirements set in 2016 are reasonable from a climate policy perspective, German energy and climate change policies seem to suffer from a coordination deficit due to limited municipal resources such as expertise and manpower. Consequently, the degree of implementation differs and individual measures at the local level can barely be coordinated (Sahner and Plachta, 2013). 
It is argued that the EnEV ignores local realities and sets standards which are out of reach, since it was solely planned at the federal level (Galvin, 2012). The Länder are tasked with monitoring their municipalities. However, Hennig (2013) argues that the Länder fulfill their monitoring tasks to very different degrees. Overall, the attempt to shift responsibility to the Länder in the sense of hierarchical top-down governance illustrates the challenges and pitfalls when it comes to multi-level governance. Länder regulations show a big discretion in their interpretation of the EnEV (Hennig, 2013). While some federal states "protect" their municipalities from strict enforcement of the EnEV, other federal states and municipalities position themselves as pioneers, putting pressure on the federal government to force laggards to comply with minimum standards.

Yet, not only the Länder pursue their own agendas; municipalities, too, have their own strategies. The Local Authorities Guideline (Kommunalrichtlinie - KRL) is a support program from the Federal Ministry of the Environment, Nature Conservation and Nuclear Safety. It serves as the main instrument of the National Climate Initiative (Göpfert, 2014) and focuses on initial advice, climate action concepts as well as climate action management. Cities can apply for funding for the position of a climate manager sponsored by the $K R L$ for three years. In addition, the ministry has introduced the Masterplan $100 \%$ Climate Action, a key characteristic of which is the financial support of so-called Masterplan Municipalities (MPK - Masterplan Kommunen). Consequently, some cities are forerunners while others are laggards.

The difference between laggards and forerunners is even more evident when we look at energy and $\mathrm{CO} 2$ policies at the Länder level. There is a major conflict between those Länder that produce a significant amount of renewable energy (such as Lower Saxony) and those relying on traditional energy production (for instance Baden-Württemberg). The latter seek to protect their home industries and fear financial as well as political costs. Consequently, they undermine the expansion of electricity grids for the transport of renewable energy from the north to the south. Furthermore, resources spent on research programs or funds made available to citizens differ from Bundesland to Bundesland, increasing the gap and illustrating difficulties of horizontal coordination. Conflicts among the Länder in terms of $\mathrm{CO} 2$ reduction related policies serve as a case to exemplify tensions in terms of horizontal policy coordination.

Conflicts not only occur among the Länder; there is also tension between the Länder and their respective municipalities. Freiburg, for instance, was prevented by its state government when it sought to designate areas for wind power plants (Späth and Rohracher, 2011; Galvin, 2012). This case illustrates challenges in terms of vertical coordination. So-called ecopoints (Ökopunkte) demonstrate a further case that underlines tensions between state governments and their respective municipalities. Ecopoints (Maurer and Schader, 2019) should compensate for the sealing of areas. For example, farmers converting a field into a meadow can claim ecopoints because a meadow is "more ecologically valuable" than a field. Municipalities and businesses are allowed to sell these points, they can even be found on $e$ Bay. The system is criticized as a modern form of indulgence trade. In Baden-Wurttemberg almost 30 percent of compensation and replacement measures were not implemented in 2019, and similar numbers can be found for Bavaria and Hesse. A survey among the 16 state governments revealed that most environment ministries do not know how many ecopoints are registered or traded in their state. Municipalities and regional governments are supposed to control ecopoints.

Local governments not only engage domestic regional and federal institutions; they also collaborate in global, transnational networks. The ICLEI, Energy Cities and the Climate Alliance represent the three biggest networks (Kern and Bulkeley, 2009). Much of this collaboration 
evolved as EU-funded projects, substantiating the multilevel governance of this policy sector in Europe. However, most cities participating in those networks are forerunners in the sustainability field, increasing the gap between leaders and laggards. Many local authorities lack necessary resources; for instance, they lack the expertise required to implement and monitor climate policies and they do not have the financial resources to comply with national legislation.

All these cases illustrate the poor vertical coordination of climate change policies in Germany. Institutional relations easily become tense when environmental issues such as the reduction of $\mathrm{CO} 2$ emissions come on the agenda. The federal government has no monopoly on setting policy objectives; the Länder are also engaged in policy making and their policies may or may not correlate with those by the federal government.

\section{Sweden}

Sweden embarked comparatively early on public policy to protect the environment. Sweden was also among the first countries to create an agency in the environmental policy sector when The Environmental Protection Agency [Naturvårdsverket] was created in 1967. This attention to the environment was later directed more specifically towards the climate change cluster of issues.

Sweden is often described as a forerunner in environmental protection and the promotion of sustainable development. While there certainly is some merit to that account there are also some specific factors that help explain Sweden's early commitment to environmental issues. First, Sweden has for a long time relied on hydro-electric and nuclear power for its supply of electric power. In 2017, hydro-electric power accounted for 40 percent of the total production of electric power and nuclear power plants generated another 40 percent. While both of these technologies have potential or real impact on the environment, they are both fossil free, hence meeting greenhouse emission reduction targets has presented less of a challenge to Sweden than for most other countries.

Secondly, Sweden has pushed climate change-related issues intensively on the international stage although the country's influence on international agreements has been marginal at best. Parts of the soft power that the government has tried to muster have been derived not just from implementing but also from over-implementing international accords and agreements, in an effort to lead by example (Zannakis, 2009).

The vertical coordination of climate change policy in Sweden is complex and fragmented. As Linander (2019) shows, central, regional and local governments use different targets for the reduction of greenhouse emission reductions and also different measures of such emissions, thereby exacerbating policy coordination problems. The Swedish case also highlights the need for central government to strike a balance between too much and too little steering and provision of guidelines to regions and cities. Interestingly, Linander (2019:32-33) shows how cities and regions criticize central government for not doing enough in this respect in the climate change policy field, stating that "cities are waiting for consistent state steering" (present authors' translation).

Thus, in vertical policy coordination, as in Spider Man, with great powers come great responsibilities. Sweden's regions and cities enjoy extensive formal autonomy in relationship to central government, yet in greenhouse emissions reduction policy, where central government seeks to take command, these autonomous institutions want more steering from the state, not less. We mentioned earlier how the divorce between formal jurisdiction on the one hand and proximity to both the sources and the solutions to greenhouse gas emission reduction is a major compli- 
cating factor. Deeply aware of this problem, cities and regions in Sweden seem to urge central government to take a higher profile on these issues in order to strengthen the vertical policy coordination (Linander, 2019).

Central government is, however, not idling on these issues. It employs legislation, regulation, and subsidies to drive environmental policies and programs. Overarching legislative frameworks such as The Environmental Code (miljöbalken) provide the judicial backbone of the environmental policy and define the roles of subnational government. The chief role of The Code is to set the goal and means of sustainable development. Frequently updated and amended, the Code serves as a foundation for regulations issued by the Environmental Protection Agency and other agencies. Subnational governments are instructed to develop sustainable plans for their physical planning.

Regional government in Sweden (landsting) is predominantly engaged in healthcare. In addition to subsidies from central government, some 90 percent of regional governments' budgets goes into health care. Swedish regional government has two components. One is the regional government based in regional elections producing a regional elected assembly. The other component is the regional tier of central government (länsstyrelse), historically referred to as "the extended arm of the King". In the area of environmental policy and climate change-related actions, the länsstyrelse plays a more important role as it oversees local governments, engages the EU structural funds, and monitors the implementation of central government programs at the regional and local levels.

For the present context we should note that regions are not a very significant environmental policy arena. The role of regions in the environmental policy sector is primarily to surveil local governments' implementation of central government policies. This is the common institutional arrangement in most unitary states.

Turning now to the local level, Swedish local governments enjoy considerable formal and de facto autonomy. While it is true that there has been a growing tendency among central government institutions to steer and control local authorities, the pattern that local governments are quite autonomous remains true.

Much of the collaboration between the public and private sector takes place at the local level. This is also where the bulk of environmental policy and sustainability programs and policies is put into action. These two aspects are closely related. Reducing greenhouse gas emissions and developing a "green economy" requires close collaboration between the city and private sector research facilities. The city of Gothenburg is a good example, having received a dozen or so international awards for its work on environmental, economic and social sustainability, in close collaboration with the city's corporate sector (see Pierre, 2019).

Moreover, European cities are increasingly networked in the sustainable development policy field. The EU's "smart cities" program supports transnational networks of cities as a means of diffusing knowledge and technologies to support a sustainable city. It is safe to say that the learning and diffusion of knowledge that takes place in these networks is at least as important to local governments as are its contacts with higher echelons of their respective national governments.

All is not well, however. Betsill and Bulkeley (2007:450) argue that there is "a lack of 'fit' between the nature of the problem to be governed and the institutions undertaking governance". This 'lack of fit' refers precisely to the disjuncture between issue ownership and political and administrative legal leverage. which is the theme of this paper. Similarly, Nilsson et al. (2012) 
note that the governance of climate change action at the local level is poorly institutionalized. Thus, the local governance of climate change-related policies and programs has been conducted to a large extent by informal networks and other forms of contextual forms of collaboration between the local government and actors in their external environment. Some might argue that informal networks and partnerships provide better opportunities for innovation than more formalized structures of collaboration, but in the longer haul it might be desirable to have a higher degree of institutionalization providing a framework for collaborative projects.

These observations refer to the horizontal governance dimension, i.e. patterns of collaboration and exchanges between the local authority and actors in the surrounding society, and less so to the vertical dimension of governance and policy coordination. In this latter dimension, as we saw earlier, national legislation gives local government a baseline definition of assignments but much of the activity in the sustainable development sector should be seen as part of the realm of the local authority's autonomy; how cities relate to the corporate sector or to international networks of cities is essentially their own choice.

\section{Comparative analysis}

In an ideal intergovernmental relationship arrangement, we would expect lower-level rulemaking to be embedded in upper-level policy objectives and regulatory frameworks. However, the autonomy of regional and local government allows subnational institutions to set their own objectives which may or may not correlate with national objectives. In other instances, cities and regions criticize central government for not coordinating sufficiently. Also, subnational government may use other measurements on greenhouse gas emissions than those used by national government, something which makes any coordinated assessment of environmental change very difficult (Linander, 2019).

These observations suggest that the targets of steering, in order to deliver good climate change policy, sometimes demand stricter steering in order to boost policy efficiency. The idea that the demand for steering sometimes exceeds the supply is not new (see Jacobsson, Pierre and Sundström, 2015) but it is nonetheless worth noting as it suggests that cities and regions may find their institutional autonomy to be an impediment to policy efficiency.

In both Germany and Sweden, the self-governing mandate grants all municipalities the right to "decide all matters relevant to the local community in their own responsibility within the frame of existing legislation" (in Germany, the Grundgesetz, article 28, section 2; in Sweden, the Instrument of Government, Chapter 1, par. 1 has an almost identical ruling). While this arrangement may vitalize local democracy, it also presents significant hurdles for vertical policy coordination and, by extension, for efficient policies to address climate change.

In both countries it is easy to note the tensions between those institutions that own the greenhouse emissions reduction issue and those that control the regulatory and financial leverage required to execute environmental protection and climate change-related policies and programs. However, the two countries have chosen somewhat different paths towards strengthening the vertical coordination of CO2-reduction policy. In Germany, the complexity and challenges of multi-level governance become evident when we look at climate change policies more broadly. The division into laggards and forerunner municipalities underlines the wickedness of the climate change policy sector, highlighting the bargain over power and resources. Since municipalities are not only embedded in the federal government structure but also of their respective Land, political interests come into play and have tremendous consequences on policy implementations. Thus, Germany serves as a case in point to illustrate the consequences of 
poorly coordinated policies. Again, cities produce most of the pollution and greenhouse gases, and while some cities address this problem by network collaboration to disseminate knowledge and help develop new technologies, there are also those that lack the necessary resources and expertise.

Meanwhile, in Sweden, which as a unitary state should offer fewer challenges to vertical policy coordination, cities and regions argue that occasionally there is a shortage of central government control and coordination. Central government has introduced (or in some cases re-introduced) instruments and levers to strengthen its control over cities and regions (Statskontoret, 2019a). This development can be seen across the full range of policy sectors in which local government is a significant agent in the delivery of services or in the implementation of programs. Here, climate change emerges as a cross-cutting issue challenging almost all areas of the local authority, urging the city to reach out to the local private sector in order to promote research and development in green technologies and also to assist in developing more environmentally friendly production processes.

As a result, many cities find themselves in a situation where they have to juggle the complex vertical multilevel governance processes against horizontal, collaborative governance to bring in businesses and stakeholders into joint projects. Thus, the Swedish case offers interesting findings. Intergovernmental relations tend to present challenges more frequently than they support $\mathrm{CO} 2$ emission policies; goal setting and target setting does not correspond across different institutional levels and the re-empowerment of central government in relationship to cities and regions has a lasting impact on policy implementation at the local level.

Furthermore, both countries substantiate the close relationship between horizontal and vertical policy coordination; poor horizontal policy coordination at the central government level creates or exacerbates problems of vertical policy coordination. In Sweden, this phenomenon was evident as the 2006-14 central government pursued several large-scale infrastructural projects, thereby allowing for increasing $\mathrm{CO} 2$ emissions, without considering how the new infrastructures would impact the prospects of reaching the CO2 policy targets (Linander, 2019).

A final observation from this comparative analysis, coming back to a previous point, is that the concept "vertical" in a multilevel governance context is not always synonymous with a topdown model of political and administrative communication but can also refer to more iterative and interactive exchanges between levels. In most other policy sectors, "vertical" coordination denotes central government instructing regions and cities on how to implements its policies and programs. However, the multilevel governance perspective of greenhouse emission reduction policy suggests that cities, as loci of collaborative public and private ventures to develop green technology to reduce emissions, sometimes are transmitters of policy ideas at least as much as they are recipients.

\section{Conclusions}

Coordinating public policy across jurisdictional borders and institutional levels has proven to be a challenge for central governments for a long time. The novelty that this paper brings to the discussion is twofold. First, we show that vertical policy coordination is essentially a twoway street; ideas and calls for action flow both top-down and bottom-up. Cities' and regions' demands for more coordination sometimes exceed central government's provision of such coordination. In the EU multilevel governance of environmental policy, broadly defined, there is additional complexity to vertical coordination when EU institutions and domestic subnational institutions engage each other directly, bypassing central governments. 
Secondly, the context where cities own issues related to the reduction of greenhouse gas emissions but lack the expertise and resources to address those issues by themselves has proven to be a powerful incentive for cities to escape the domestic institutional hierarchy and seek collaboration with other cities and also with the local business community. In other words, when the vertical supply of resources dries up, many (not all) cities explore horizontal avenues to collaboration. This strategy is likely to exacerbate vertical policy coordination problems in the future. It is also likely to increase the gap between cities that lead the development towards reducing $\mathrm{CO} 2$ emissions and the laggards. Thus, there is a vicious circle at work; when vertical policy coordination fails, regions and cities often find themselves pitted in horizontal-level competition for financial and other resources, something which further exacerbates the vertical policy coordination challenges.

Such vicious circles can be arrested. Central government has, on occasion, and in extraordinarily challenging circumstances, stepped in and overruled even constitutionally guaranteed local government mandates. For instance, in response to a major financial crisis in Sweden in 1991 and 1992, central government chose to override local governments' authority to set their own tax levels and imposed a cap on local taxes. The decision was justified with reference to the economic crisis and the concern that local governments would significantly raise taxes. Also, the measure was explicitly short-term. Enforcing national decisions on autonomous cities and regions is ultimately a matter of weighing costs against benefits.

Against this background further research should include more cases with regard to the degree of autonomy of local government (Ladner, Keuffer and Baldersheim, 2015), and analyze different ways in which central/federal government can control local authorities enjoying different degrees of autonomy. One could, for instance, compare a state with a high degree of autonomy (Germany or Sweden), a medium degree (the Netherlands) and a low degree (United Kingdom).

The root cause of the complexity of vertical policy coordination is that these issues sit at the juncture of two constitutional principles. One is the assertion that central government's decisions and action should cover the entire realm. The other principle, related to the idea of subsidiarity, states that local (and often also regional) government should be granted some degree of autonomy so that it can respond to local demands and needs. In most countries, this apparent contradiction is resolved through a system of either assigning different policy areas to different institutional levels, or ensuring that essentially all levels are involved, with functional differentiation, in all or most policy areas. In both models, but primarily in the latter model, the Parker principle of linking authority to accountability constitutes a significant obstacle to vertical policy coordination.

\section{Bibliography}

Adam, C.,Hurka, S., Knill, C., Peters, B.G., \& Steinebach, Y. (2019). Introducing Vertical Policy Coordination to Comparative Policy Analysis: The Missing Link between Policy Production and Implementation, Journal of Comparative Policy Analysis, 21(5), 499-517.

https://doi.org/10.1080/13876988.2019.1599161

Bache, I., \& Flinders, M. (Eds.) (2004). Multi-level Governance. Oxford: Oxford University Press.

Betsill, M., \& Bulkeley, H. (2006). Cities and the multilevel governance of global climate change. Global Governance, 12, 41-59. 
Betsill, M., \& Bulkeley, H. (2007). Looking Back and Thinking Ahead: A Decade of Cities and Climate Change Research. Local Environment, 12, 447-456.

Bulkeley, H., \&Betsill, M. (2005). Rethinking Sustainable Cities: Multilevel Governance and the 'Urban' Politics of Climate Change. Environmental Politics, 14, 42-63.

Bulkeley H., \& Kern, K. (2006). Local government and the governing of climate change in Germany and the UK. Urban Studies, 43, 2237-2259.

FitzGibbon, J., \& Mensah, K. O. (2012). Climate Change as a Wicked Problem: An Evaluation of the Institutional Context for Rural Water Management in Ghana. SAGE Open.

https://doi.org/10.1177/2158244012448487

Galvin R. (2012). German Federal Policy on Thermal Renovation of Existing Homes: A Policy Evaluation. Sustainable Cities and Society, 4, 58-66.

Göpfert, C. (2014), Der Beitrag von Klimaschutzkonzepten zum kommunalen Klimaschutz. Eine empirische Analyse zusätzlicher Effekte von im Rahmen der Kommunalrichtlinie geförderten Klimaschutzkonzepten auf die lokalen Klimaschutzaktivitäten. (Masterarbeit Universität Hagen). Wuppertal: Wuppertal Institut für Klima Umwelt Energie.

Gore, C. (2010). The Limits and Opportunities of Networks: Municipalities and Canadian Climate Change Policy. Review of Policy Research, 27, 27-46.

Gurr, T. R., \& King, D. S. (1987). The State and the City. Basingstoke: Macmillan.

Gustafsson, G. (1987). Decentralisering av politisk makt [Decentralization of Political Power]. Stockholm: Carlssons.

Hammer, S., Kamal-Chaoui, L., Robert, A., \& Plouin, M. (2011). Cities and Green Growth: A Conceptual Framework. OECD Regional Development Working Papers, 2011/08.

Head, B., \& Alford J. (2015). Wicked problems: Implications for Public Policy and Management. Administration and Society, 47, 711-739.

Hennig, F. (2013), Energieeffizienz und erneuerbare Wärme in Gebäuden. Herausforderungen am Beispiel des Vorreiter-Bundeslandes Baden-Württemberg. Diplomarbeit am Fachbereich Bauingenieurwesen und Geodäsie. TU Darmstadt.

Hooghe, L., \& Marks, G. (2003). Unraveling the State, but How? Types of Multi-level Governance. American Political Science Review, 97, 233-243.

Hustedt, T. (2014). Inter-Ministerial Coordination in Germany: A Working Group in Climate Policy, in P. Lægreid, K. Sarapuu, L. H. Rykkja \& T. Randma-Liiv (Eds.), Organizing for Coordination in the Public Sector. Public Sector Organizations (pp.153-162). London: Palgrave Macmillan.

IPCC (2014). Climate Change 2014: Synthesis Report. Contribution of Working Groups I, II and III to the Fifth Assessment Report of the Intergovernmental Panel on Climate Change. (Core Writing Team, R.K. Pachauri and L.A. Meyer (Eds.)]. IPCC, Geneva, Switzerland.

Jacobsson, B., Pierre, J., \& Sundström, G. (2015), Governing the Embedded State: The Organizational Dimension of Governance. Oxford: Oxford University Press.

Juncker, J-C. (2015). State of the Union 2015. Time for Honesty, Unity and Solidarity. Brussels: EU Commission.

Kern, K., \& Bulkeley, H. (2009). Cities, Europeanization and Multi-level Governance: Governing Climate Change through Transnational Municipal Networks. Journal of Common Market Studies, 47, 309-332. 
Ladner, A. Keuffer, N. and Baldersheim, H. (2016) Measuring Local Autonomy in 39 Countries (1990-2014), Regional \& Federal Studies, 26:3, 321-357.

https://doi.org/10.1080/13597566.2016.1214911

Linander, O. (2019). Klimatstrategier i osynk: En studie av målkongruens mellan styrnivåer med fokus på klimatmålen i Göteborgs stad, Västra Götaland och Sverige [Climate strategies out of synch: A study of goal congruence between levels of governing with focus on climate goals in the City of Gothenburg, the West Sweden region and the government of Sweden].Mimeo, Gothenburg: Department of Political Science, University of Gothenburg.

Majone, G. (1997). From the Positive to the Regulatory State: Causes and Consequences of Changes in the Mode of Governance. Journal of Public Policy, 17, 139-167.

Maurer, N., \& Schader, N. (2019). Moderner Ablasshandel. Tagesschau.de.

Retrieved from https://www.tagesschau.de/investigativ/report-mainz/oekokonto-101.html

McCallum, S., Dworak, T., Prutsch, A., Kent, N., Mysiak, J., Bosello, F., Klostermann, J.,Dlugolecki, A., Williams, E., König, M., Leitner, M., Miller, K., Harley, M., Smithers, R.,Berglund, M., Glas, N., Romanovska, L., van de Sandt, K., Bachschmidt, R., Völler, S.,\& Horrocks, L. (2013). Support to the development of the EU Strategy for Adaptation to Climate Change: Background report to the Impact Assessment, Part I - Problem definition, policy context and assessment of policy options. Vienna: Environment Agency Austria.

Meadowcroft, J. (2007). Who is in Charge here? Governance for Sustainable Development in a Complex World. Journal of Environmental Policy and Planning, 9(3-4), 299-314.

Nevens, F., Frantzeskaki N., Gorissen, L., \& Loorbach, D. A. (2013). Urban Transition Labs: Cocreating transformative action for sustainable cities. Journal of Cleaner Production, 50, 111-122.

Nilsson, A. E., Gerger Swartling, Å., \& Eckerberg, K. (2012). Knowledge for Local Climate Change Adaptation in Sweden: Challenges of Multilevel Governance. Local Environment 17, 751-767.

O’Flynn, J., Blackman, D., \& Halligan, J. (Eds.) (2013). Crossing Boundaries in Public Management and Policy: The International Experience. London: Routledge.

Peters, B. G. (1998). Comparative Politics: Theory and Method. New York, NY: NYU Press.

Peters, B. G. (2015). Pursuing Horizontal Management: The Politics of Policy Coordination. Lawrence, KA: University Press of Kansas.

Peters, B. G. (2018). The challenge of policy coordination. Policy Design and Practice, 1(1), 1-11.

Peters, B. G., \& Pierre, J. (2001). Developments in Intergovernmental Relationships: Towards MultiLevel Governance. Policy and Politics, 29, 131-135.

Peters, B. G., \& Pierre, J. (2004). Multi-level Governance and Democracy: A Faustian Bargain?. In I. Bache \& M. Flinders (Eds.), Multi-level Governance (pp. 79-92). Oxford: Oxford University Press.

Piattoni, S. (2010). The Theory of Multi-Level Governance: Conceptual, Empirical, and Normative Challenges. Oxford: Oxford University Press.

Pierre, J. (2019). Multi-level governance as a strategy to build policy capacity in cities: Evidence from Sweden. Journal of Urban Affairs, 41, 103-116.

Pierre, J. (2020). Nudges against pandemics: Sweden's Covid-19 containment strategy in perspective. Policy and Society, 39, 478-493.

Przeworski, A. (1987). Methods of Cross-National Research, 1970-1983: An Overview. In M. Dierkes et al. (Eds.), Comparative Policy Research: Learning from Experience (pp.31-49). Aldershot: Gower. 
Przeworski, A., \& Teune, H. (1970). The Logic of Comparative Social Inquiry. New York: John Wiley and Sons.

Rhodes, R. A. W. (1986). The National World of Local Government. London: Allen and Unwin.

Sahner, G., \& Plachta, T. (2013). Auswirkungen künftiger Energiestrukturen auf den Wohnungsund Städtebau. Mauerwerk, 17, 332-342.

Sharp E. B., Daley, D.M., \& Lynch, M.S. (2011). Understanding Local Adoption and Implementation of Climate Change Mitigation Policy. Urban Affairs Review, 47, 433-445.

Späth, P., \& Rohracher, H. (2011). The 'eco-cities' Freiburg and Graz: The social dynamics of pioneering urban energy and climate governance. In H. Bulkeley (Ed.), Cities and low carbon transitions (pp. 88-106). London: Routledge.

Statskontoret (2019a), Utveckling av den statliga styrningen av kommuner och landsting: En analys (Rapport 2019:2). Stockholm: Statskontoret.

Statskontoret (2019b), Förvaltningspolitik i förändring (Dnr 2019/6-5). Stockholm: Statskontoret.

Torfing, J., Peters, B. G., Pierre, J., \& Sörensen, E. (2012), Interactive Governance: Advancing the Paradigm. Oxford: Oxford University Press.

Verhoest K., \& G. Bouckaert, G. (2005). Machinery of Government and Policy Capacity: The Effects of Specialization and Coordination. In M. Painter \& J. Pierre (Eds.) Challenges to State Policy Capacity (pp. 92-111). London: Palgrave.

Wurster S., \& Köhler, C. (2016). Die Energiepolitik der Bundesländer. In A. Hildebrandt \& F. Wolf (Eds.). Die Politik der Bundesländer (pp. 283-314). Wiesbaden: Springer.

Zannakis, M. (2009), Climate Change as a Window of Opportunity: Sweden and Global Climate Change. $\mathrm{PhD}$ dissertation. University of Gothenburg: Department of Political Science. 